\title{
Analysing the Impact of Managerial Ownership on the Performance of Shariah-Compliant Firms in Pakistan
}

\author{
Naveeda K Katper ${ }^{1,2,3}$, Sanober Salman Shaikh ${ }^{3}$, Vivake Anand ${ }^{4}$, Najma Imtiaz $\mathrm{Ali}^{5}$ \\ ${ }^{1}$ Department of Syriah and Management, Academy of Islamic Studies, University of Malaya, Malaysia \\ ${ }^{2}$ Jalan Universiti, 50603 Kuala Lumpur, Wilayah Persekutuan Kuala Lumpur, Malaysia \\ ${ }^{3}$ Institute of Business Administration, Faculty of Commerce and Business Administration, University of Sindh, \\ Allama I.I. Qazi Campus, 76080, Jamshoro, Pakistan \\ ${ }^{4}$ Department of Management Sciences, Isra University Hyderabad Sindh, Pakistan \\ ${ }^{5}$ Department of Information System, Kulliyah of Information Communication and Technology(KICT), \\ International Islamic University Malaysia, Gombak, Kuala Lumpur, Malaysia. \\ Correspondence: Sanober Salman Shaikh, Jalan Universiti, 50603 Kuala Lumpur, Wilayah Persekutuan Kuala \\ Lumpur, Malaysia.
}

Received: July 4, 2018

doi:10.5539/ibr.v11n11p55
Accepted: October 8, $2018 \quad$ Online Published: October 11, 2018

URL: https://doi.org/10.5539/ibr.v11n11p55

\begin{abstract}
This paper analyses the impact of managerial ownership upon firm performance in the Shariah-compliant firms of Pakistan. Agency theory that suggests involving managers as part of firm's ownership can help firms reduce the agency cost, has widely been applied in the corporate setup of conventional finance, however, there is growing need of academic research to find out the role and application of this theory in the Shariah-compliant organizations. All around the Muslim world, there is the rise of Shariah-compliant firms; however, little work has been done to critically evaluate such important concepts based on agency theory, it is, therefore, an optimistic approach to familiarise the idea of firm performance with the relationship of managerial ownership under Agency Theory in such organizations. In order to better understand the acceptability and adaptability of Agency Theory, the objective of this study is to examine the impact of managerial ownership upon firm performance in Shariah-compliant firms of Pakistan for the first time. This paper is based upon panel data and regression models applied to the sample of 68 Shariah-compliant firms listed on Pakistan's Karachi Stock Exchange covering five years from 2009 to 2013. This paper tests the firm performance through two different dependent variables Tobin's Q and ROA by regressing through OLS, Fixed effect (FE) and Random effect(RE) methods. Both models are proved empirically significant. The robust results confirm that managerial ownership (MO) has a positive and strong impact upon firm performance (Q)/ (ROA) in the Shariah-compliant firms of Pakistan. The outcomes may provide a good understanding and help in making a better decision regarding investment on the ethical grounds. It proves that more concentrated managerial ownership produces the higher firm profits. It can be also inferred that the increased proportion of managerial ownership tends to align with the interests of owners and thus help to reduce the agency conflict in our sample of Shariah-compliant firms in Pakistan. Moreover, Size (LNTA) has a positive relationship with firm performance (Q)/ (ROA) viewing that the Shariah-compliant firms depend on retained earnings. It may be due to the restricted criterion on the leverage for Shariah-compliant firms by the board of Shariah compliance. Leverage (DAR) is negatively and significantly correlated with profitability and growth (GROW) is positively and significantly correlated with firm performance (Q). In the developing and Muslim world, this study may reserve a unique place due to its virgin attempt and highlight the ignored aspect in the body of literature. These findings are of great benefit to investment managers, and Shariah cautious and other ethical investors regarding investment and portfolio related decisions.
\end{abstract}

Keywords: firm performance, managerial ownership, Shariah-compliance

\section{Introduction}

Agency theory proposes that the separation of ownership and management of the firm causes a serious agency conflict. The agents (managers) run a business on behalf of widely spread shareholders. This creates a typical agency related problem for the firms (Eisenhardt, 1989). The opportunistic behaviour of managers exacerbates 
this problem when they make decisions for their benefits at the cost of shareholders' interest (Jensen \& Meckling, 1976). However, agency theory suggests that the conflicts between firms' management and owners could be resolved if managers partially own the firm they run (Jensen \& Meckling, 1976). Therefore, managerial ownership is perceived to be one of the key determinants of firm performance. Literature observes that the firm performance improves when ownership and managerial interest are merged through concentration of ownership (Agrawal \& Mandelker, 1990). The financial performance is one of the indicators of judging the performance of managers and their self-serving behaviour (Hillman, Keim, \& Luce, 2001). Although there exists a large body of research on the ownership-performance relationship from the conventional finance perspective, this aspect is noticeably ignored from the perspective of Islamic finance and Shariah-compliant firms.

The growing number of Shariah-compliant businesses captures our attention for their unique characteristics distinguishing them from the conventional enterprises. Shariah compliance leads firms to follow certain guidelines which include maintaining a restricted level debt in the capital structure and keeping a certain level of liquid assets in the asset mix of the firms (Bellalah et al. 2013). Katper et al. (2017) further discovered that Shariah-compliant firms in Pakistan on average have shorter debt maturities in their total borrowing structure. Moreover, shariah teachings obligate agents to practice due diligence in the best interest of the principal (Sarker 1999; Katper et al. 2015). These factors make the Shariah-compliant firm a unique corporate entity which calls for exclusive investigation of a managerial role in maximizing the wealth of the shareholders and avoiding the selfish and opportunistic behaviour. Hence, we explore whether Shariah-compliant firms differ in the relationship between performance and managerial ownership.

Islam also emphasizes the role of justice, selflessness, and trustworthiness in a principal-agent relationship. Kahf (1992) discusses that the Islamic economic system emphasizes that market should work with justice, commiseration, and solidarity. Siddiqi (1988) mentioned that the goal of an economic firm is to make reasonable profits that may be different from profit maximization in the neoclassical sense due to ethical and social factors affecting the production decision. el-Din and Seif (2008), mention that Islam is against the axiom of selfishness. This provides evidence that managerial self-interest is discouraged in Islamic teachings. All these factors make it relevant to study the role of managers in improving firm performance among the Shariah-compliant firms. However, the problem is no prior study on such real issue regarding agency conflict and relationship between managerial ownership and firm performance is focused. As the matter of fact, the agency is judged on the grounds of either mitigating the problems or increasing those with other stakeholders. Therefore, this study is useful for the practical purpose and will help stakeholders and investors in investing decisions.

Collecting the financial and accounting data on Shariah-compliant firms from Pakistan for the period 2009 to 2013, we discover the positive and significant relationship between managerial ownership and firm performance. These findings corroborate agency cost perspective that increasing managerial ownership aligns otherwise conflicting of managers' and shareholders' interest in the Shariah-compliant firms. The paper is further organized as follows. Section 2 provides a literature review. Section 3 gives hypothesis development. The model specification, data and sample, and variable description are presented in section 4 . Section 5 is dedicated to the analysis of results whereas section 6 concludes the study.

\section{Literature Review and Hypothesis Development}

Corporate governance is considered an imperative part of an organization because it is concerned with the all operating activities, therefore; it is useful for all the stakeholders beyond only single party such as stockholders (Aras \& Crowther, 2008). Numerous studies have been found on the matter of the relationship between firm performance and corporate governance. Nevertheless, there is no such research on the managerial ownership and firm performance in the connection of Shariah-compliant firms despite the concept of Shariah-compliant firms is growing fast especially in the Muslim world. The issue of corporate governance is directly related to the agency conflict theory as the managers are the agents of the owners and the separation of two parties may involve in the clash of their interests. The seminal research concerning owner-manager relationship is led by Jensen \& Meckling, (1976). Various attempts have been made afterwards to mitigate this agency problem by a great number of authors, yet, the problem is unresolved and different studies are inconsistent in this context. In the literature, the agency problem is recurrently highlighted in the conventional firms as well as in the Shariah-compliant firms (Sarker, 1999).

Since the agency problem is significantly concentrated in the Islamic teachings. Islam emphasizes performing managerial role and responsibilities with honesty. Though many studies evaluate different aspects regarding this agency problem including managerial ownership and firm performance conventionally, yet the issue is ignored from the perspective of Shariah-compliant firms. Even so, the literature on conventional firms provides 
inconsistent results on the relationship between firm performance and ownership structure too. The various studies focus on the impact of concentrated ownership and/or diffused ownership in relation to firm performance and find diverse results. For example, Berle \& Gardiner, (1932) imply that diffused ownership adversely affects the firm performance.

A good volume of research took place on such opportunistic managerial approach in this regard. Various authors attempted to explore managerial self-interest pursuit in different ways (Bethel \& Liebeskind, 1993; Hoskisson, Johnson, \& Moesel, 1994). The authors argue that the firm performance improves when ownership and managerial interest are merged through concentration of ownership (Agrawal \& Mandelker, 1990). It is because key equity holders' build concentrated ownership and thus reduce the cost of the agency at a considerably low level. Moreover, block holders may be opportunistically excerpt firms' resources for their personal benefits which exert an adverse effect on the value of the firm.

In this vein, the literature observes that managerial ownership is one of the determinants of firm performance. For investigating the relationship between ownership structure and firm performance various authors find significant relationship Demsetz 1983; Demsetz \& Lehn, 1985). Though a good volume of research is conducted, the findings are inconsistent with leaving the room for further analysis. Different studies find mixed results hence the matter is unresolved as one cluster of studies finds a positive relationship. The other band of research discovers the negative relationship. However, the third and fourth groups observe a curvilinear relationship and no relationship between ownership and performance respectively.

For instance, Porta et al. (1997, 1998, 1999, and 2000) find the positive effect of ownership concentration and profitability. They argued that in the weak legal environment, the positive association between profitability and the ownership is greater (Porta et al. 2002). It is also expected that firms with better investment opportunities, better corporate governance practices should have a higher valuation. Claessens \& Djankov, (1999) find a positive relation in ownership concentration and firm profitability and labour productivity for the Czech Republic firms from 1992 to 1997. Several other studies find a significant and positive relationship between concentrated ownership and firm performance (Gedajlovic \& Shapiro, 1998; Gedajlovic \& Shapiro, 2002; Kang \& Shivdasani, 1995; Shleifer \& Vishny, 1986; Short, 1994; Thomsen \& Pederson, 2000; Kapopoulos \& Lazaretou, 2007). Consequently, the literature suggests that when profitable investment opportunities are there, the controlling shareholders divert to concentrated ownership and corporate valuation becomes higher.

However, Cho \& Kim, (2007) examined the effect of outside directors on firm performance on the firms in Korea and found mixed results. They observe a positive relationship between outside director effectiveness (outside director participation rate) and firm profitability and a negative moderating effect regarding large shareholder ownership and managerial ownership. Also, a positive moderating effect when it comes to blockholder ownership. They specify that outside directors had a positive but weak impact on firm performance. Outside shareholders had weak and less power to monitor large controlling shareholders. The same effect was found by Javid \& Iqbal, (2008) who explore the relationship between ownership concentration and firm's performance and conclude that with increasing profitable opportunity, controlling equity holders distract to the concentrated ownership and the firm value becomes high, thus, they observe the positive effect on firms' profitability. However, they maintain the negative relation between corporate governance practices and disclosures and transparency with a concentration of ownership.

In this connection, Craswell, Taylor, \& Saywell, (1997) find a curvilinear relationship between insider ownership and corporate performance. But, the findings do not support the institutional ownership as an important determinant of Australian firms' performance. It is also observed that the higher firm profitability requires a less diffused ownership. On the Jordanian industrial and service companies, Alabdullah et al. (2014) find the negative relationship between board size and firm performance. They further observed that the independent directors in the board exert no impact on the firm's financial performance. Similarly, their result shows no association of CEO with the firm financial performance. However, recently in 2016, research on the service sector of the Jordanian firms was conducted by the same author Alabdullah, (2016) and evaluated firm performance by using the accounting measures as dependent variables return on assets (ROA) and return on equity (ROE). In this study, he observed that the measures of board size affect the two variables i.e. return on assets (ROA) and return on equity (ROE) positively and significantly while the firm size showed no association with the firm performance. Likewise, the author finds no evidence of the relationship between managerial ownership and firm performance ROA and ROE. Afterwards, within the span of two year the same author Alabdullah, (2018), discovers that managerial ownership exerts positive influence on the firm performance. However, they identify that firm size and foreign ownership has no association with firm performance. 
Consequently, from the literature, we observe some studies showing that the managerial ownership is not a determinant of firm performance such as Demsetz \& Villalonga, (2001) and Chang, (2003) catch no evidence for the relationship between ownership and firm performance. They find no significant relationship between the two variables due to the distributed ownership supporting the idea that diffused ownership may not align the owner-manager interests. Hence, it may exaggerate some agency problems.

From the Shariah-compliance perspective, other areas are focused but this particular dimension regarding firm performance is ignored in the non-financial sector of developed, developing and Muslim world. However, a recent study in 2014 is conducted on CSR and firm performance for the financial companies Banks. The research is conducted to explore corporate social responsibility (CSR) and financial performance in the financial sector i.e. banks by (Mallin, Farag, \& Ow-Yong, (2014). The authors by taking the sample of 90 Islamic banks from 13 countries find a positive relationship between and financial performance. They also observed the significant relationship between Shariah supervisory board (SSB) size and corporate social responsibility (CSR) discloser index. Moreover, their research indicates that Islamic banks involve in the range of social activities. They observed that Islamic banks are more committed to the vision as well as mission, top management and financial product and service dimensions. However, less focus is paid to environment dimension. They are attentive in accounting and auditing while less focused on voluntary CSR disclosure. Hence, there is a shortage of research in the literature regarding Shariah-compliant firms in this research on agency based issue to examine relationship between managerial ownership and firm performance. Therefore, it is highly needed to explore the diverse aspects considering the fast growing Shariah-compliant business round the world.

Convincingly, the available empirical research established on the relationship between firm performance and ownership structure is conducted on conventional firms but still inadequate and incompatible and/or inconsistent. Nonetheless it is rarely found from the Shariah-compliant non-financial sector. To realise this fact from a different angle, we attempt to assess the managerial ownership and performance in Shariah-compliant firms. Based on our empirical evidence, we can infer the managerial tendency to align the interest of stakeholders and reduce the agency problem. Since the managerial ownership is not directly investigated with firm performance in Shariah-compliant firms. Therefore, this research would be a new beginning in this area and contribute to the literature of vital importance providing practical evidence to the academia, other beneficiary parties, policy makers and investors in the developed, developing and/or the Muslim world particularly Pakistan.

\subsection{Research Hypothesis}

Based on agency separation hypothesis, we test the argument by Jensen and Meckling (1976) that managers have divergent motives which can affect firm performance. More strikingly, the literature indicates that managerial discretion creates agency costs normally by two ways. First managers engage in short run cost-increasing activities planned to enhance their nonsalary income, or to provide other forms of on-the-job consumption (Williamson, 1964; Jensen and Meckling, 1976). This behaviour decreases the corporate profits by increasing the costs. Second, managers tend to satisfy their needs for prestige, power, and status (Baumol, 1959), over-invest in long-run projects to maximize size and growth rather than corporate profits (Marris, 1964; Grabowski and Mueller, 1972; Jensen \& Warner, 1988). This is also observed that such self-interested manoeuvring occurs when managers over-diversify (Amihud and Lev, 1981). In this situation, managers invest in negative NPV projects thus decreasing the firm profits. Though short-run cost increase and self-interest planning reveal two different routes, both ways if managerial discretion exists, firm performance will decrease.

In the absence of managerial incentives and effective monitoring, discretionary behaviour among the management rises. However, managerial participation in corporate ownership would incentivize the managers to work in the overall best interests of the owners (Jensen and Meckling, 1976). Based on this argument, the following hypothesis is developed and tested.

\section{H0: The managerial ownership does not affect the profitability of the firm.}

\section{H1: The managerial ownership has a positive/negative effect on the profitability of the firm.}

\section{Methodology}

\subsection{Data and Sample Size}

The main sources of data for this study comprise the balance sheet, income statement, and ownership data for the companies listed on Karachi Stock Exchange (KSE) of Pakistan. The data on balance sheet variables and income statement were extracted from the annually published financial statements of non-financial companies listed on Karachi Stock Exchange 2008 to 2013. The secondary data are published by the State Bank of Pakistan (SBP), the central bank of the country. This source is considered as one of the authoritative sources of data on Pakistani 
corporate sector. The publication tabulates yearly the most valuable data on each company listed on KSE. We extracted the ownership data of firms by locating each company's financial statements for each year of the sample period from their respective websites. In Pakistan, firms are required to publicize their pattern of shareholding in the annual report as per the basic requirements of the Securities and Exchange Commission of Pakistan (SECP), the watchdog for the corporate sector in Pakistan. We collected the firms that made the Shariah compliance list for all the years that is from 2009 to 2013. This made our sample relatively more balanced. As balanced data records observations of the same unit every time, it reduces noise and heterogeneity normally observed in the unbalanced panel. Following this procedure, we collected the data for 68 Shariah-compliant firms from 2009 to 2013 for five years yielding our sample to 340 firm-year observations. We, however, were limited to the availability of ownership data; therefore, we collected balanced panel data containing these firms.

\subsection{Model and Variables Description}

This section contains the model description and definitions of variables. This study proposes the quantitative method of research and implies the econometric model on multiple regression models. We use the econometric model to test our hypothesis regarding the relationship between performance and managerial ownership following by some prior studies (Klein, Shapiro, \& Young, 2005). We developed two equations based on two different proxies for firm performance, Tobin's Q and Return on assets (ROA). Equation (1) uses Tobin's Q as the dependent variable and equation (2) applies returns on assets (ROA) as the dependent variable for the robustness check of results (Cui \& Mak, 2002). The main explanatory/independent variable is the managerial ownership (MO) and others are control variables in the model based on two equations. The two equations having two different dependent variables are given below.

\subsubsection{Models}

$$
\begin{array}{r}
Q=\alpha_{0}+\beta_{1} \text { Managerial Ownership } \\
+\beta_{5} \text { Growth }_{i t}+\varepsilon_{i} \text { Size }_{i}+\beta_{3} \text { Tangiblity }_{i t}+\beta_{4} \text { Leverage }_{i t}
\end{array}
$$

$$
\begin{gathered}
\text { ROA }=\alpha_{0}+\beta_{1} \text { Managerial Ownership }_{i t}+\beta_{2} \text { Size }+\beta_{3} \text { Tangiblity }_{i t}+\beta_{4} \text { Leverage }_{i t} \\
+\beta_{5} \text { Growth }_{i t}+\varepsilon_{i}
\end{gathered}
$$

\subsubsection{Description of Variables}

a) Firm performance: We use Tobin's Q and ROA as the two main proxies for firm performance.

Following Klapper and Love (2004), Tobin's Q was computed as follows.

$$
Q_{i t}=\left(M V E_{i t}+T D_{i t}\right) / B V A_{i t}
$$

Where $Q$ is Tobin's Q, $M V E$ is the market value of equity, $T D$ is total debt, $B V A$ is book value of total assets, and $i$ and $t$ are firm and time subscripts.

For the robustness, the dependent variable ROA is measured as the five-year mean return on assets which is used as an alternate measure to check the robustness of the results.

b) The explanatory variable: Managerial ownership is the main explanatory variable which is measured as a ratio of shares held by the management and a total number of equity shares.

c) The control variables: Managerial ownership is not the sole determinant of a firm's profitability. Hence the literature identifies various other factors affecting the performance of the firm. The effect of these factors is, therefore, important to isolate. Following Cui and Mak (2002), we control for the effects of firm size, tangibility, leverage, and growth. All variables are defined in Table 1 below. 
Table 1. Definition of variables

\begin{tabular}{ll}
\hline Variables & Measurement of variables \\
\hline $\begin{array}{l}\text { Dependent variable: } \\
\text { Tobin's Q }\end{array}$ & $\begin{array}{l}\text { The ratio of market value of equity plus total debt to the book value of } \\
\text { assets. }\end{array}$ \\
$\begin{array}{l}\text { Neturn on Assets (ROA) } \\
\text { Explanatory variable: }\end{array}$ & The fraction of managerial ownership in total equity, \\
$\begin{array}{l}\text { Managerial Ownership (MO) } \\
\text { Control variables: }\end{array}$ & $\begin{array}{l}\text { Natural logarithm of total assets. } \\
\text { Size (LNTA) }\end{array}$ \\
$\begin{array}{l}\text { Tangibility (TANG) } \\
\text { Leverage (DAR) } \\
\text { Growth (GROW) }\end{array}$ & $\begin{array}{l}\text { Total debt to total asset ratio } \\
\text { Annual \% change in sales }\end{array}$ \\
\hline
\end{tabular}

\section{Results and Discussion}

\subsection{Descriptive Statistics}

Table 2 describes the descriptive statistics of the variables individually. We observe that the firm performance is 21.5 and 10.8 for $\mathrm{Q}$ and ROA respectively ranging from negative to positive profits indicating Tobin's $\mathrm{Q}$ value relatively higher. The fraction of the concentration of managerial ownership is around $15 \%$ in our sample of Shariah-compliant firms. An average Shariah-compliant firm has total assets of PKR 7275.4 million. The tangibility is around $40 \%$ whereas, as expected we notice that the debt ratio is averaging around $16 \%$ ranging from 0 to around 37\%. Moreover, the mean of growth in Shariah-compliant firms is however $20 \%$ and fluctuating from negative to a positive range.

Table 2. Descriptive statistics

\begin{tabular}{|c|c|c|c|c|c|}
\hline Variable & Obs & Mean & Std. Dev. & Min & Max \\
\hline $\mathbf{Q}$ & 340 & 21.551 & 33.720 & -98.460 & 158.680 \\
\hline ROA & 340 & 10.779 & 12.987 & -19.930 & 46.480 \\
\hline MO & 337 & 15.402 & 23.660 & 0.000 & 76.400 \\
\hline TA (PKR ml) & 339 & 7275.4 & 192.4 & 26.10 & 281319.0 \\
\hline TANG & 338 & 0.399 & 0.246 & 0.017 & 0.894 \\
\hline DAR & 338 & 0.164 & 0.176 & 0.000 & 0.366 \\
\hline GROW & 337 & 19.935 & 32.938 & -47.624 & 165.070 \\
\hline
\end{tabular}

4.2 Correlation Analysis

Table 3 presents the correlation for our sample of Shariah-compliant firms. Managerial ownership is positively correlated with both Q and ROA and is significant. Managerial ownership is negatively correlated with firm size, whereas, it is positively correlated with growth indicating that managers in firms with fewer assets and higher growth rates hold more equity shares. This seems consistent with the evidence that managers align their interests with those of owners of higher growth firms with the relatively lower assets base (Smith and Watts, 1992; Gaver and Gaver, 1993). Profitability (ROA) and firm size (LNTA) are positively correlated. However, ROA has a negative correlation with tangibility (TANG) and leverage (DAR). The size is positively correlated with ROA, and a similar correlation with $\mathrm{Q}$ depicting that large firms have a higher potential and the productive ability for future profitability growth. Larger firms may have more growth opportunities as compared to smaller firms. Moreover, firms with higher assets base have lower fixed assets ratios.

Table 3. Correlation matrix

\begin{tabular}{|c|c|c|c|c|c|c|c|}
\hline & $\mathbf{Q}$ & ROA & MO & LNTA & TANG & DAR & GROW \\
\hline $\bar{Q}$ & 1.0000 & & & & & & \\
\hline ROA & $0.8078 *$ & 1.0000 & & & & & \\
\hline MO & $0.0044 *$ & $0.1224 *$ & 1.0000 & & & & \\
\hline LNTA & $0.2568 *$ & $0.2484 *$ & $-0.3042 *$ & 1.0000 & & & \\
\hline TANG & $-0.2476^{*}$ & $-0.3421 *$ & $0.3029 *$ & $-0.1187 *$ & 1.0000 & & \\
\hline DAR & $-0.2008^{*}$ & $-0.2878^{*}$ & $0.2157 *$ & -0.0818 & $0.5084 *$ & 1.0000 & \\
\hline GROW & 0.0634 & 0.0402 & $0.1511 *$ & $-0.1242 *$ & 0.0680 & $0.2036^{*}$ & 1.0000 \\
\hline
\end{tabular}

4.3 OLS Regression, Fixed Effect, and Random Effect

Dependent Variables: Tobin's Q and ROA

We apply pooled OLS, Fixed effect, and Random effect models to test the relationship between managerial ownership (MO) and firm performance (Q)/ (ROA) in Pakistani shariah-compliant firms. In the first specification, Tobin's $Q$ is used as the main proxy for firm performance. The results are reported in Table 3 and 4. 
The main explanatory variable of interest in the regression is managerial ownership (MO). For determining which method is appropriate among all methods we apply the Hausman test which is developed and incorporated in the different programs Such as Eviews and Stata and others. We used Stata to answer the question either the Fixed effect is appropriate for the analysis or Random effect. The Hausman test shows that the random effect model (REM) is the better choice because of the P-value making it insignificant.

In our Findings, all regressions show a positive relationship between managerial ownership (MO) and Q, which is consistent with the hypothesis that firms performance enhances as a result of increased managerial ownership (Jensen \& Meckling, 1976). The results are empirically similar to those found in previous studies (Claessens \& Djankov, 1999; Porta et al. 2000).

As for other explanatory variables, our research outcomes show a positive relationship between size (LNTA) and the dependent variable firm performance $(\mathrm{Q})$ as well as (ROA) in the two equations. Hence, the Shariah-compliant firms depend on retained earnings due to the restricted criterion on the leverage also following the pecking order theory of capital structure (Ahmed, 2007). Moreover, it can be concluded that when there exists the economy of scale in large firms, there is expected a positive relationship between profitability and size (Baumol, 1959; Hall and Weiss, 1967; Shepherd, 1972; Markides 1995). Following this, our study is consistent with the notion that Shariah-compliant firms rely on internal funds (Retained earnings) more than the external financing. However, from the conventional side, the results may be mixed such as Craswell et al. (1997) examine that firm size is negatively correlated with profitability. This indicates that the conventional firms, in contrast to the Shariah-compliant firms, may rely on external funding more than the internal one.

Table 3. Regression analysis of Tobin's Q on managerial ownership

The table reports the OLS, FE, and RE results of Eq. 1. The dependent variable is Tobin's Q (Q). The explanatory variable is Managerial ownership (MO). The regression controls the effects of firm size (LNTA), tangibility (TANG), leverage (DAR), and growth (GROW). All variables are explained in Table 1. The Hausman test shows that the random effect is the better choice.

\begin{tabular}{lccc}
\hline & Pooled OLS & Fixed Effects & Random Effects \\
\hline MO & $\mathbf{0 . 2 1 4 * *}$ & $\mathbf{0 . 0 9 5 *}$ & $\mathbf{0 . 2 0 0 * *}$ \\
& $(\mathbf{2 . 6 3 )}$ & $\mathbf{( 0 . 5 5 )}$ & $\mathbf{( 1 . 8 8 )}$ \\
LNTA & $4.957 * * *$ & 6.506 & $(3.68)$ \\
& $(4.97)$ & $(0.97)$ & $-25.324 *$ \\
TANG & $-27.062^{* *}$ & -27.653 & $(-2.35)$ \\
& $(-3.18)$ & $(-1.63)$ & $-29.660^{*}$ \\
DAR & $-25.576^{*}$ & -32.905 & $(-2.17)$ \\
& $(-2.17)$ & $(-1.76)$ & $0.110^{*}$ \\
GROW & $0.112^{*}$ & 0.104 & $(2.23)$ \\
& $(2.08)$ & $(1.96)$ & $-55.272^{*}$ \\
Constant & $-47.245^{* *}$ & -68.362 & $(-2.23)$ \\
\hline F/ Wald test & $(-2.81)$ & $(-0.63)$ & $36.02 * * *$ \\
R_sq & $11.589^{* * *}$ & $2.896 * *$ & 0.1505 \\
N & 0.151 & 0.053 & 331 \\
Hausman test & 331 & 331 & 1.13 \\
p-value & & & 0.951 \\
\hline
\end{tabular}

$* \mathrm{p}<0.05 ; * * \mathrm{p}<0.01$

The result in table 3 shows that the random effect model is appropriate according to the Hausman test and is considered as the better choice.

Our result demonstrates that the negative and significant relationship between the coefficient of leverage (DAR) and firm performance in both models $(\mathrm{Q})$ and (ROA). Similar results are reported in the case of conventional firms by Kapopoulos \& Lazaretou, (2007). One of the possible explanations for this relationship in Shariah-compliant firms may be the ceiling of debt ratio. Consequently, the Shariah-compliant firms do not rely much on the debt financing like conventional firms with the unrestricted debt limit. The rationality behind this phenomenon is when the firms utilize their retained earnings they save the cost of external financing thus by reducing the cost of capital, firm's profitability increases. However, our findings are contradictory to those by Craswell et al (1997) they find a positive relationship between leverage and firm performance. The growth has a positive and significant relationship with firm performance in both models which specifies that the firm performance also depends on the firm growth opportunities.

\subsection{Robustness Check}

To verify the robustness of our findings, we performed additional analysis replacing Tobin's Q with accounting 
measure of performance return on assets (ROA). Results are reported in Table 4. We find the consistent results in both equations 1 and 2 on the measures of Q and ROA respectively. In the following table, the Hausman test shows that the random effect is the better choice.

Table 4. Robustness check: Regression analysis of ROA on managerial ownership

The table reports the OLS, FE, and RE results of Eq. 2. The dependent variable is the return on assets (ROA). The explanatory variable is Managerial ownership (MO). The regression controls the effects of firm size (LNTA), tangibility (TANG), leverage (DAR), and growth (GROW). All variables are explained in Table 1.

\begin{tabular}{|c|c|c|c|}
\hline & Pooled OLS & Fixed Effects & Random Effects \\
\hline \multirow[t]{2}{*}{$\mathrm{MO}$} & $0.014 * *$ & $0.026^{*}$ & $0.003 * *$ \\
\hline & $(0.46)$ & $(0.54)$ & $(0.07)$ \\
\hline \multirow[t]{2}{*}{ LNTA } & $1.463 * * *$ & 2.503 & $1.772 * *$ \\
\hline & $(3.91)$ & (1.34) & $(2.76)$ \\
\hline \multirow[t]{2}{*}{ TANG } & $-13.240 * * *$ & $-10.640 *$ & $-11.247 * *$ \\
\hline & $(-4.14)$ & $(-2.25)$ & $(-3.00)$ \\
\hline \multirow[t]{2}{*}{ DAR } & $-12.385 * *$ & $-13.321 *$ & $-13.802 * *$ \\
\hline & $(-2.80)$ & $(-2.56)$ & $(-3.13)$ \\
\hline \multirow[t]{2}{*}{ GROW } & $0.043^{*}$ & $0.033^{*}$ & $0.035^{*}$ \\
\hline & $(2.11)$ & $(2.21)$ & $(2.43)$ \\
\hline \multirow[t]{2}{*}{ Constant } & -5.934 & -22.484 & -11.201 \\
\hline & $(-0.94)$ & $(-0.74)$ & $(-1.05)$ \\
\hline F/ Wald test & $15.184 * * *$ & $5.728 * * *$ & $52.76 * * *$ \\
\hline R_sq & 0.189 & 0.100 & 0.1851 \\
\hline $\mathrm{N}^{-}$ & 331.000 & 331.000 & 331.000 \\
\hline Hausman test & & & 2.23 \\
\hline p-value & & & 0.897 \\
\hline
\end{tabular}

The Shariah-compliance is a fast-growing concept worldwide. Various factors contribute to this trend, for instance, the increasing interest of investors because of its secured mode of investment and growing Muslim population as the second largest religion in the world. Islamic finance is expected to grow faster in the near future especially after the Muslim millennials' involvement in applying Islamic investment concepts to cater for the complex investment and consumption needs of modern society. With the rise in commodity prices and income in the current global economy, the appetite for Shariah investments is expected to continue to improve in the future. Given this scenario, we expect our results to be insightful for Shariah-cautious and other ethical investors.

This study is important from the Islamic perspective due to growing concept in the business, especially in the Muslim world. Prior literature has not focused this aspect to explore the impact of managerial ownership on the firm performance in the Shariah-compliant firms. Therefore, this study will be the major add-in to the literature. Moreover, the agency perspective is worth due to the very clear and focused concentration of Islamic teachings about the agents or managers of any organization in the context of being Ameen and trustworthy remaining on the job (Katper et al. 2015, Sarker 1999). Shariah compliance gives the instruction not to insight any conflict with the contractual party due to your own benefits. Managers being safeguard of the property and wealth of owners and other stakeholders ought not to exploit it in a harmful way for others.

The agency theory perspective is important due to assuming the core responsibilities performed by the managers within any organization regarding the key matters especially achieving the goal of the firm by satisfying the key stakeholders along with moral and ethical considerations. Whereas the institutional theory emphasis on social structure and behaviours including guidelines about norms and rules to adopt. However, we have highlighted the Islamic facet in this study where the Shariah-compliant firms are bound to follow some criteria to work under Shariah-compliance. Consistently, we find some particular features regarding the behaviour of explanatory variable managerial ownership (MO). We observe that increasing level of ownership enhance the level of profitability showing positive relationship between two variables. This result specifies the tendency to align the interests of ownership and control of the firm which is required by the Islamic teachings to avoid the conflict with the contractual parties.

In previous literature, the fact is identified for the managerial ownership that the self-interested manoeuvring occurs when managers over-diversify (Amihud and Lev, 1981). In this situation, managers invest in negative NPV projects thus decreasing the firm profits. Though short-run cost increase and self-interest planning reveal 
two different routes, both ways if managerial discretion exists, firm performance will decrease. Unlike this outcome, our results show increasing firm performance when managerial ownership increases by positive relationship, thus, managerial discretion does not decrease the profitability of the firm. Our findings reject the null hypothesis and indicate that managerial ownership affects the firm performance as expected in the Shariah-compliant firms and tends to reduce agency conflict by aligning the interests of key stakeholders. Our result is also in contrast with the findings of research by Alabdullah, (2016), on the Jordanian non Shariah-compliant companies, who finds no effect of managerial ownership on both ROA and ROE. However, later on the same writer Alabdullah, (2018), observes that managerial ownership positively impacts on firm performance.

Moreover, we discover some diverse characteristics of Shariah-compliant firms by applying OLS, fixed and random effect models to test the hypothesis. The Hausman test shows that the random effect is the better choice. Accordingly, our results show that leverage (DAR) is significantly and negatively related to firm performance (Q) and (ROA) in Shariah-compliant firms. The result is behaving according to the pecking order theory of capital structure. With the increase in profits, the debt size decreases specifying the importance of retained earnings in the firm's capital structure and managerial financial decision making. The Shariah-compliance restricts the level of debt ratio/leverage obtained by the Shariah-compliant firms, which is less than $40 \%$ in the capital structure of these firms. Realizing this mentioned fact, the Shariah-compliant firms are utilizing their retained earning instead of relying on the heavy debts. It is also postulated by Ahmed (2007) that the Sharia-compliant firms focus and prefer retained earnings and owner equity on the higher proportions of Debt Financing. Our findings in this regard provide the evidence which is a unique characteristic of Shariah-compliance firms which is not necessarily restricted in the traditional or conventional firms. This result also seems to satisfy the criterion set by Shariah-compliance authorities to limit the leverage at the certain level. Hence, this result is consistent with the notion that Shariah-compliant firms follow the pecking order theory for building their capital structure. Moreover, the results show that the size and firm performance are positively correlated in Shariah-compliant firms. The big firms, with the growing assets, tend to earn more profits. Hence, the analysis provides some diverse facts about the Shariah-compliant firms that may have financial investment implications for the different stakeholders.

\section{Conclusion}

Agency problem is a serious issue for the firms because it increases the costs of the firm. There is also a problem of the clash in the interest of different parties thus the alignment of interests among all stakeholders is a challenging task. Although a significant volume of research is conducted on the matter, however, still the issue seems unresolved. This study is a first attempt at probing the managerial behaviour regarding the performance of the Shariah-compliant firms. We seek to explore the relationship between managerial ownership and firm performance in the shariah-compliant firms. This paper provides new indications on the relationship between firm performance and corporate governance in the Shariah-compliant firms. This study observed some new insights regarding the agency issue and profitability of the firms.

Our findings show that managerial ownership (MO) is positively and significantly correlated with the performance $(\mathrm{Q}) /(\mathrm{ROA})$ of the Shariah-compliant firms. Hence, the managerial ownership is perceived to be one of the key determinants of firm performance in Shariah-compliant firms. This result indicates that in the scenario of increased numbers of ownership in the management, the profitability also increases. The managers, in this case, are working in the direction where owner-manager can catch the target of aligning their interests being major stakeholders of the firm. We observed that there is a positive relationship between size (LNTA) and firm performance $(\mathrm{Q})$. It indicated that the Shariah-compliant firms relatively depend on retained earnings more than the conventional firms due to the restricted criterion on the leverage. This result is consistent with the notion that Shariah-compliant firms follow the pecking order theory for building their capital structure. Further, our results show that leverage (DAR) is significantly and negatively related to firm performance. Hence we discover some diverse behaviours of variables in Shariah-compliant firms.

This study contributes in a number of ways to the existing body of literature by having new evidence by testing the relationship between managerial ownership and firm performance empirically for the Shariah-compliant firms. This paper is the first attempt, according to the knowledge of authors, on the research and analysis made for the Shariah-compliant firms in the developing and Islamic countries of the world. By discovering the diverse characteristics of Shariah-compliant firms regarding managerial ownership and profitability, ethical and Muslim investors/ stakeholders would make their investment decisions in a better way. Exclusively when the investors would perceive and know the substantiation of aligning the interests of owner-manager by growing level of managerial ownership and thus plummeting the agency conflict or cost in the Shariah-compliant firms. 


\section{References}

Agrawal, A., \& Mandelker, G. N. (1990). Large shareholders and the monitoring of managers: The case of antitakeover charter amendments. Journal of Financial and Quantitative analysis, 25(2), 143-161. https://doi.org/10.2307/2330821

Ahmed, H. (2007). Issues in Islamic corporate finance: capital structure in firms. IRITI Research Paper Series, 70.

Alabdullah, T. T. Y. (2018). "The relationship between ownership structure and firm financial performance: Evidence from Jordan", Benchmarking: An International Journal, 25(1).

Alabdullah, T. T. Y., Yahya, S., \& Ramayah, T. (2014). Corporate governance mechanisms and Jordanian companies' financial performance. Asian Social Science, 10(22), 247.

Alabdullah, T. T. Y. (2016). Are Board Size And Ownership Structure Beneficial In Emerging Markets' Firms? Evidence From Jordan. International Journal of Management \& Information Systems, 20(3), 87.

Amihud, Y., \& Lev, B. (1981). Risk reduction as a managerial motive for conglomerate mergers. The Bell Journal of Economics, 605-617. https://doi.org/10.2307/3003575

Aras, G., \& Crowther, D. (2008). Governance and sustainability: An investigation into the relationship between corporate governance and corporate sustainability. Management Decision, 46(3), 433-448. https://doi.org/10.1108/00251740810863870

Baumol, W. J. (1959). Business behaviour, value and growth. New York, 32.

Bellalah, M., Rehman, A. A., \& Masood, O. (2013). Syariah Compliant Screening Practices: Thema (THéorie Economique, Modélisation et Applications), Université de Cergy-Pontoise.

Berle, A. A., \& Gardiner, C. (1932). Means, The modern corporation and private property. New York: Commerce Clearing House.

Bethel, J. E., \& Liebeskind, J. (1993). The effects of ownership structure on corporate restructuring. Strategic Management Journal, 14(S1), 15-31. https://doi.org/10.1002/smj.4250140904

Chang, S. J. (2003). Ownership structure, expropriation, and performance of group-affiliated companies in Korea. Academy of Management Journal, 46(2), 238-253.

Cho, D. S., \& Kim, J. (2007). Outside directors, ownership structure and firm profitability in Korea. Corporate Governance: An International Review, 15(2), 239-250. https://doi.org/10.1111/j.1467-8683.2007.00557.x

Claessens, S., \& Djankov, S. (1999). Ownership concentration and corporate performance in the Czech Republic. Journal of comparative economics, 27(3), 498-513. https://doi.org/10.1006/jcec.1999.1598

Craswell, A. T, Taylor, S. L., \& Saywell, R. A. (1997). Ownership structure and corporate performance: Australian evidence. Pacific-Basin Finance Journal, 5(3), 301-323. https://doi.org/10.1016/S0927-538X(96)00028-5

Cui, H., \& Mak, Y. T. (2002). The relationship between managerial ownership and firm performance in high R\&D firms. Journal of Corporate Finance, 8(4), 313-336. https://doi.org/10.1016/S0929-1199(01)00047-5

Demsetz, H., \& Lehn, K. (1985). The structure of corporate ownership: Causes and consequences. Journal of political economy, 93(6), 1155-1177. https://doi.org/10.1086/261354

Demsetz, H., \& Villalonga, B. (2001). Ownership structure and corporate performance. Journal of corporate finance, 7(3), 209-233. https://doi.org/10.1016/S0929-1199(01)00020-7

Demsetz, H. (1983). The structure of ownership and the theory of the firm. The Journal of Law and Economics, 26(2), 375-390. https://doi.org/10.1086/467041

Eisenhardt, K. M. (1989). Agency theory: An assessment and review. Academy of management review, 14(1), 57-74. https://doi.org/10.5465/amr.1989.4279003

el-Din, T., \& Seif, I. (2008). Economic Analysis and Moral Policy: A Textbook of Islamic Economics: Leicester: The Islamic Foundation.

Gaver, J. J., \& Gaver, K. M. (1993). Additional evidence on the association between the investment opportunity set and corporate financing, dividend, and compensation policies. Journal of Accounting and economics, 16(1-3), 125-160. https://doi.org/10.1016/0165-4101(93)90007-3

Gedajlovic, E. R., \& Shapiro, D. M. (1998). Management and ownership effects: Evidence from five countries. 
Strategic Management Journal, 533-553. https://doi.org/10.1002/(SICI)1097-0266(199806)19:6<533::AID-SMJ957>3.0.CO;2-\#

Gedajlovic, E., \& Shapiro, D. M. (2002). Ownership structure and firm profitability in Japan. Academy of Management Journal, 45(3), 565-575.

Grabowski, H. G., \& Mueller, D. C. (1972). Managerial and stockholder welfare models of firm expenditures. The Review of Economics and Statistics, 9-24. https://doi.org/10.2307/1927491

Hall, M., \& Weiss, L. (1967). Firm size and profitability. The Review of Economics and Statistics, 319-331. https://doi.org/10.2307/1926642

Hillman, A. J., Keim, G. D., \& Luce, R. A. (2001). Board composition and stakeholder performance: Do stakeholder directors make a difference? Business \& Society, 40(3), 295-314. https://doi.org/10.1177/000765030104000304

Hoskisson, R. E., Johnson, R. A., \& Moesel, D. D. (1994). Corporate divestiture intensity in restructuring firms: Effects of governance, strategy, and performance. Academy of Management Journal, 37(5), 1207-1251.

Javid, A. Y., \& Iqbal, R. (2008). Ownership concentration, corporate governance and firm performance: Evidence from Pakistan. The Pakistan Development Review, 643-659. https://doi.org/10.30541/v47i4IIpp.643-659

Jensen, M. C., \& Warner, J. B. (1988). The distribution of power among corporate managers, shareholders, and directors. Journal of Financial Economics, 20, 3-24. https://doi.org/10.1016/0304-405X(88)90038-4

Jensen, M. C., \& Meckling, W. H. (1976). Theory of the firm: Managerial behavior, agency costs and ownership structure. Journal of Financial Economics, 3(4), 305-360. https://doi.org/10.1016/0304-405X(76)90026-X

Kahf, M., \& Khan, T. (1992). Principles of Islamic financing. research paper, 16.

Kahf, M. (1992). Market Structure: Free Cooperation.

Kang, J. K., \& Shivdasani, A. (1995). Firm performance, corporate governance, and top executive turnover in Japan. Journal of financial economics, 38(1), 29-58. https://doi.org/10.1016/0304-405X(94)00807-D

Kapopoulos, P., \& Lazaretou, S. (2007). Corporate ownership structure and firm performance: evidence from Greek firms. Corporate Governance: An International Review, 15(2), 144-158. https://doi.org/10.1111/j.1467-8683.2007.00551.x

Katper, N. K., Madun, A., Syed, K. B., \& Tunio, M. N. (2017). Determinants of debt maturity structure in Shariah and non-Shariah firms in Pakistan: A comparative study. Journal of Applied Economic Sciences, 12, $1210-1225$.

Katper, N. K., Madun, A., \& Syed, K. B. S. (2015). Does Shariah Compliance lead to Managerial Trustworthiness? Evidence from empirical analysis of Capital Structure of Shariah and Non-Shariah Firms in Pakistan. Editorial Board, 10(7), 37.

Klein, P., Shapiro, D., \& Young, J. (2005). Corporate governance, family ownership and firm value: the Canadian evidence. Corporate Governance: An International Review, 13(6), 769-784. https://doi.org/10.1111/j.1467-8683.2005.00469.x

La Porta, R., Lopez-de-Silanes, F., Shleifer, A., \& Vishny, R. (2000). Investor protection and corporate governance. Journal of Financial Economics, 58(1), 3-27. https://doi.org/10.1016/S0304-405X(00)00065-9

Mallin, C., Farag, H., \& Ow-Yong, K. (2014). Corporate social responsibility and financial performance in Islamic banks. Journal of Economic Behavior \& Organization, 103, S21-S38. https://doi.org/10.1016/j.jebo.2014.03.001

Markides, C. C. (1995). Diversification, restructuring and economic performance. Strategic Management Journal, 16(2), 101-118. https://doi.org/10.1002/smj.4250160203

Marris, R. (1964). The economic theory of managerial capitalism. London: Macmillan. https://doi.org/10.1007/978-1-349-81732-0

Porta, R. L., Lakonishok, J., Shleifer, A., \& Vishny, R. (1997). Good news for value stocks: Further evidence on market efficiency. The Journal of Finance, 52(2), 859-874. https://doi.org/10.1111/j.1540-6261.1997.tb04825.x

Porta, R. L., Lopez-de-Silanes, F., Shleifer, A., \& Vishny, R. W. (1998). Law and finance. Journal of Political 
Economy, 106(6), 1113-1155. https://doi.org/10.1086/250042

Porta, R., Lopez-de-Silanes, F., \& Shleifer, A. (1999). Corporate ownership around the world. The Journal of Finance, 54(2), 471-517. https://doi.org/10.1111/0022-1082.00115

Porta, R., Lopez-de-Silanes, F., Shleifer, A., \& Vishny, R. (2002). Investor protection and corporate valuation. The Journal of Finance, 57(3), 1147-1170. https://doi.org/10.1111/1540-6261.00457

Sarker, M. A. A. (1999). Islamic business contracts, agency problem and the theory of the Islamic firm. International Journal of Islamic Financial Services, 1(2), 12-28.

Shepherd, W. G. (1972). The elements of market structure. The Review of Economics and Statistics, 25-37. https://doi.org/10.2307/1927492

Shleifer, A., \& Vishny, R. W. (1986). Large shareholders and corporate control. The Journal of Political Economy, 461-488. https://doi.org/10.1086/261385

Short, H. (1994). Ownership, control, financial structure and the performance of firms. Journal of economic surveys, 8(3), 203-249. https://doi.org/10.1111/j.1467-6419.1994.tb00102.x

Siddiqi, M. N. (1988). Islamic banking: theory and practice. Banking in South East Asia, Singapore: Institute of Southeast Asian Studies, 34-67.

Smith, C. W., \& Watts, R. L. (1992). The investment opportunity set and corporate financing, dividend, and compensation policies. Journal of Financial Economics, 32(3), 263-292. https://doi.org/10.1016/0304-405X(92)90029-W

Thomsen, S., \& Pedersen, T. (2000). Ownership structure and economic performance in the largest European companies. Strategic Management Journal, 689-705. https://doi.org/10.1002/(SICI)1097-0266(200006)21:6<689::AID-SMJ115>3.0.CO;2-Y

Williamson, O. E. (1964). The economics of discretionary behavior: Managerial objectives in a theory of the firm. Englewood Cliffs, N. Prentice-Hall.

\section{Copyrights}

Copyright for this article is retained by the author(s), with first publication rights granted to the journal.

This is an open-access article distributed under the terms and conditions of the Creative Commons Attribution license (http://creativecommons.org/licenses/by/4.0/). 